\title{
The Modification of Traditional Games to Improve the Adaptability Children with Intellectual Disability
}

\author{
Esty Zyadatul Khasanah ${ }^{1}$, Gunarhadi ${ }^{2}$, and Asrowi ${ }^{3}$ \\ \{zyadatul16@student.uns.ac.id ${ }^{1}$, gunarhadi@fkip.uns.ac.id², asrowi@yahoo.com³ \\ 1,2,3 Graduate of Special Education, Universitas Sebelas Maret, Indonesia
}

\begin{abstract}
There are many ways can be done to improve the ability of selfadjustment for intellectual disability child. One of them is by organizing play activity with traditional games. This play activity makes children directly involved in aspect of cognitive, affective and psychomotor. Traditional games are found in many places with different names, which is used in this research, namely engklek, sack race, jump rope, kucing dan tikus, boi-boian and bentengan, then modification. This research aims to determine the effectiveness of traditional games to improve the adaptability of intellectual disability children at SLB Harmony Autism Special School in Surakarta. The subjects of this research were 30 intellectual disabilitystudents. This research used a development method, means that research which aims to develop and produce products. Data obtained through questionnaires in the form of Likert-scale were analyzed by the following steps: change the results of the checklist data into quantitative data, calculate the total score in each aspect, the percentage score for each aspect of the obtained assessment is converted into a traditional game modification quality category. In conclusion, the modification traditional game effective for improve the adaptability of intellectual disability children.
\end{abstract}

Keywords: intellectual disability children, traditional game modification, adaptation

\section{INTRODUCTION}

Children with intellectual disability are part of children with special needs who experience mental development disorders. The disorder shows limited intellectual function that is below the average and the limitations of adaptive functions. According to idea stated that intellectual disability is a condition in which intelligence development experiences obstacles so that it does not reach the optimal development stage [17][5][18][19]. Also stated that "intellectual disability or intellectual retarded children (MR) have below average intelligence or mental ability \& a lack of skills necessary for day to day living. They can \& do learn new skills, but more slowly" [16]. One of stage of development is the same as the adaptation development. Children who experience mental development disorders in the development of adaptation or 
adaptation can be observed by the senses [3]. Intellectual disability children will tend to experience difficulties in understanding and interpreting the norms of the surrounding environment, also known as adaptation [5]. Adaptation is a variation in the activities of an organism to overcome an obstacle and satisfy needs and emphasize a harmonious relationship with the physical and social environment [2][7][9][11].

Things that affect the ability of adaptation come from the characteristics of intellectual disability children, including intelligence, attention to the social environment (relating to the ability of observation, memory and concentration) and other mental functions such as language, emotions, adaptation and personality. Determining an approach to social interaction in children needs to pay attention to the conditions, abilities and characteristics of the children it self [12]. Children with intellectual disability need a special design so that their adaptation abilities experience optimal development. One of them is the modification of traditional games to improve adaptation of intellectual disability children [2]. It must be adjusted to the conditions, abilities and characteristics, so that children can actively participate in activities related to the socialization of the surrounding environment that is playing [8].

People tend to regard strange behavior with intellectual retarded children because they have a level of intelligence below the intelligence of normal children. If this cannot be stopped, the child will get unfair treatment from the community and friends. Modification of traditional games for intellectual disability children provides deeper meaning, not only as an approach to social interaction that must be followed and not an activity that is difficult to follow and boring, but also as an approach that makes a fun activity, one of them with interesting activities for intellectual retarded children, that is by playing. Through play activities children can achieve physical, intellectual, emotional and social development especially in the development of adaptation abilities that are found in their emotions and social [7] [8].

\section{METHOD}

This research is a development research. Development research is a type of research that aims to develop and produce a product. The product of this research is a guide to traditional game modification to improve adaptation to intellectual disability children [1][4][13][14][15]. The location of the study was at Harmony Autism Special School. It is located at Jl. Sungai Indragiri No. 70 Dadapsari RT 01/ RW 03, Sangkrah, Pasar Kliwon, Surakarta, Central Java. Data obtained through interviews, observation and documentation. Interviews were carried out on teachers regarding modification of traditional games to improve the adjustment of intellectual disability children. Observations were made on 30 intellectual disability students to modify traditional games to improve self-adaptation. While documentation is taken from documents in the form of photos during game activities [10]. The obtained data are then represented and analyzed.

\section{FINDING AND DISCUSSION}

The results of the interview with the teacher regarding the modification of traditional games to improve the adjustment of intellectual retarded children are as follow. The importance of traditional games; to improve the self-adjustment of intellectual disability children, the Harmony Autism Special School teacher agreed to use traditional games. The proper use of traditional games to improve self-adjustment; the teacher strives to choose the type of traditional game that is suitable for intellectual disability children so they can adapt. Student's participation and success in traditional games to improve self-adaption; this research 
shows the participation and increasing success rate of intellectual disability children in traditional games so that they can adapt better. Proper modification of the traditional game to improve adaptability; the Harmony Autism Special School teachers agree to use traditional game modifications as an effort to improve the adaptation of intellectual disabled children.

The Results of data analysis in this study using quantitative data analysis. Data obtained through questionnaires in the form of Likert-scale were analyzed by the following steps: change the results of the checklist data into quantitative data, calculate the total score in each aspect, the percentage score for each aspect of the obtained assessment is converted into a traditional game modification quality category, so the conclusions can be drawn regarding the quality of traditional game modifications. The percentage score of traditional game modification is then based on score interpretation criteria [1][4][15].

The results of data analysis between the pretest and posttest showed an increase in selfadaptation abilities. This is shown in the descriptive results of self-adaptation abilities of intellectual disabled children in The Harmony Autism Special School. Based on the pretest results from 30 children, $76 \%$ of them ( 23 children) had low self-adaptation abilities, $23 \%$ of them ( 7 children) had moderate adaptation ability. Based on aspects of self-adaptation, namely personal and social adaptation that intellectual retarded children at The Harmony Autism Special School generally are in low category. This is indicated by the results of personal adaptation pretest, there are $70 \%$ (21 children) have low self-adaptation, and $30 \%$ (9 children) have moderate adaptation. While social adjustment of 30 children, there were $80 \%$ (24 children) of low adjustment ability and $20 \%$ (6 children) of moderate adjustment ability.

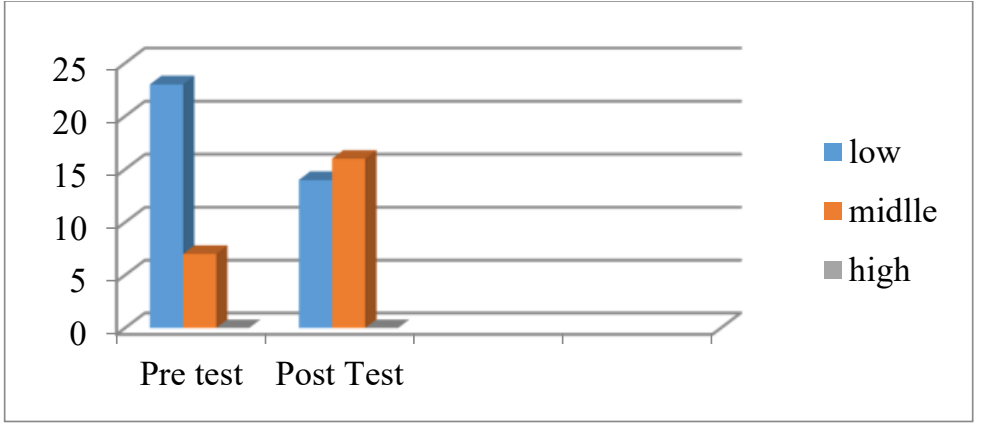

Fig. 1 Personal adaptation of intellectual disability children

This traditional game modification consists of 6 games, they are engklek, sack race, jump rope, kucing dan tikus, boi-boian and bentengan [10]. This traditional game modification refers to different characteristics, needs and abilities in intellectual disability children. This modification makes the game become creative, innovative and fun. Posttest results showed an increase in personal self-adaptation ability increased to $46 \%$ (14 children) low self-adaptation and $54 \%$ (16 children) moderate adaptation. The ability of social adaptation increased to $40 \%$ (12 children) low self-adaptation, and as much as 60\% (18 children) moderate social adaptation ability. This increased self-adaptation ability occurs because this activity is packaged in the form of games that are very suitable for children, giving children the opportunity to train senso-motorically and physically, giving them the opportunity to respect friends, team work, so that personal and social development can develop better, can train communication of intellectual disability children, can train intellectual disabled children to manage their behavior. This method provides a direct experience on the subject so that it easily captures the essence of that experience. So it can be concluded that traditional game 
modification is effective to improve the self-adaptation ability of intellectual disability children at The Harmony Autism Special School.

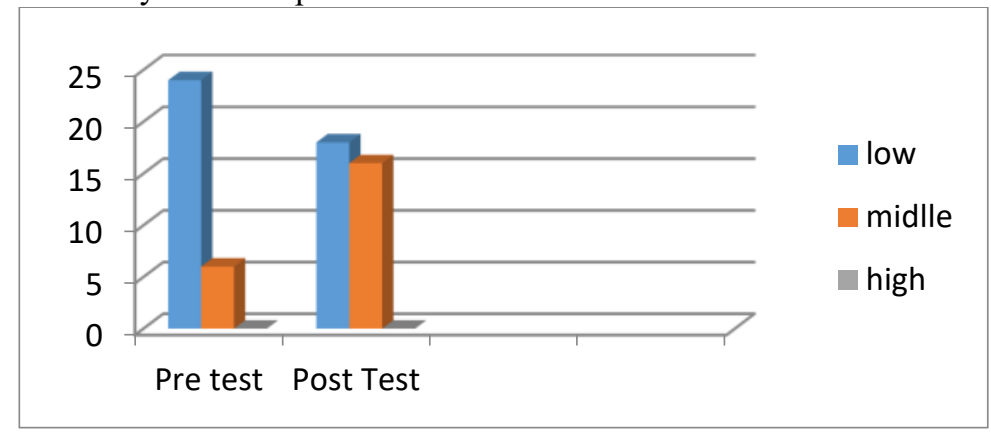

Fig. 2 Social adaptation ability of intellectual disability children

The result of the acquisition of adaptability in personal adaptation and social adaptation of children with intellectual disability can be seen that there has been an increase in the indicators that have been planned starting from pre-test to post test. In the pre-test personal abilities and social adaptation is still categorized as low, so do repairs on the post test. Well post-test personal abilities and social adaptation showed improvement. Mentally retarded children have problems adjusting to the environment and personality problems. So it needs a corresponding need for retarded children namely educational services, both therapy and behavior therapy play therapy, and out-door approach to learning. Adaptability concerning aspects of the individual's personality in its interaction with the environment inside and outside himself. Following a behavioral framework, social skills are viewed as specific behaviors that allow a person to respond to social demands and to maximize social reinforcements at home, at school, and in a variety of leisure contexts. Most definitions of social skills agree that social skills are interactive, acquired primarily through learning, and entail both initiation and inhibition of social responses [20].

The game is one of intense experiences and practices will result in control of self-adjusting capabilities. In addition, playing with peers with traditional games can have a positive impact on the child's adjustment aspects. The use of serious games is fairly accepted by this population because they do not feel the pressure existing in the real world, feeling comfortable to explore the virtual world. Furthermore, they feel that there is no risk in testing various behaviour at their own pace, obtaining an immediate feedback on their actions [21]. Modification of traditional games for children with intellectual challenges provide a deeper meaning in social interaction approach. Modification of this traditional game consists of 6 games, namely game engklek, sack race, jump rope, kucing and tikus, betengan and boi-boian. Based on research "on outbound management training to improve the adaptability children with intellectual challenges" conducted found that in order to improve the ability of children with intellectual challenges adjustment being by organizing play activities in the form of Outbound Management Training (OMT). This model game makes children directly involved in cognitive, affective, and psychomotor. The research use Outbond management with 11 games in SLBN Rembang and the result effective for increasing self-adaption intellectual disabled children. [6]. 


\section{CONCLUSION}

Based on the results of the research and discussion conducted by the researcher it can be concluded that the modification of traditional games is effective in improving the adaptation of intellectual disability children at the Harmony Autism Special School. This can be seen with the increasing aspects of self-adaptation, namely personal and social adjustment shown by intellectual disability children. This research produced a product of a guidebook on modification of traditional games to improve the ability of intellectual disability children and the media of teaching game models that are creative, innovative and fun.

\section{REFERENCES}

[1] Ahmad Tanzeh, "Pengantar Metode Penelitian",Yogyakarta: Teras, 2009.

[2] Ardiwinata A.A, Suherman, \& Dinata, M, "Olahraga Tradisional", Tangerang: CV. Cerdas Jaya, 2006.

[3] Behr, A. K, Rodger, S., \&Mickan, S, "A comparison of the play skills of preschool children with and without developmental coordination disorder", American Occupational Therapy Foundation, 33 pp. 198-208, 2013.

[4] Benny A. Pribadi, "Desain Dan Pengembangan Program Pelatihan Berbasis Kompetensi: Implementasi Model ADDIE", Jakarta: Prenada Media Group, 2014.

[5] E, Kosasih, "Cara Bijak Memahami Anak Berkebutuhan Khusus", Bandung: Yrama Widya, 2012.

[6] Gadis Mulia Wati, "Outbound Management Training Untuk Meningkatkan Kemampuan Penyesuaian Diri Anak Tunagrahita“, Educational Psychology Journal 1 (1) (2012).

[7] Geniofam, "Mengasuh dan Mensukseskan Anak Berkebutuhan Khusus". Yogyakarta: Gerai Ilmu, 2010.

[8] Ismail, A, "Education Games. Menjadi Cerdas Dan Ceria Dengan Permainan Edukatif", Yogyakarta: Pilar Media, 2006.

[9] Kemis, Ati Rosnawati, "Pendidikan Anak Berkebutuhan Khusus Tunagrahita, Jakarta: Luxima Metro Media, 2013.

[10] Laksono, Bambang, dkk, "Kumpulan Permainan Rakyat Olahraga Tradisional", Jakarta: Kementrian Pemuda dan Olahraga Republik Indonesia, 2012.

[11] Ria Ulfatusholiat, "Peran Orangtua Dalam Penyesuaian Diri Anak Tunagrahita", Psychology Journal, 2010.

[12] Santoso, Satmoko Budi, "Sekolah Alternatif Menapa Tidak?", Yogyakarta: Diva Press, 2010.

[13] Sudjana, "Metode Statistik", Bandung: PT. Tarsito, 2004.

[14] Sugiyono, "Metode Penelitian Pendidikan Pendekatan Kuantitatif, Kualitatif, Dan R\&D”, Bandung: Alfabeta, 2010.

[15] Suharsimi Arikunto, “Manajemen Penelitian”, Jakarta: Rineka Cipta, 2010.

[16] Suhasini Paramane, "Mainstreaming Mentally Retarded Children Through Inclusive Education Under SSA - A", Journal on Education (JED) Vol.3 No.2.68-73, 2016.

[17] Tjutju Sutjihati Somantri, "Psikologi Anak Luar Biasa". Bandung: Refika Aditama, 2006.

[18] Wardani,"Pengantar Pendidikan Luar Biasa", Jakarta: Universitas Terbuka, 2008.

[19] Yusak S, "Introduksi Pada Anak Berkelainan", Bandung: Sinar Baru, 2003. 
[20] Denis G. Sukhodolsky And Eric M. Butter, Social Skills Training For Children With Intellectual Disabilities, Svny262-Jacobson, Doi: 10.1007/0-387-32931-5_30 Publisher: 0887-6177, 2007.

[21] Rita Marques Tome, Joao Madeiras Pereira and Manuel Oliveira, Using Serious Games for Cognitive Disabilities, Project PEst-OE/EEI/LA0021, 2013. 